zeszyt 162, 2020, 31-47

doi: 10.4467/20833113PG.20.011.13098

Instytut Geografii i Gospodarki Przestrzennej UJ

Komisja Geograficzna, Polska Akademia Umiejętności

Wydawnictwo Uniwersytetu Jagiellońskiego

\title{
ARCHITEKTURA UCZELNI WYŻSZYCH. WYBRANE KRYTERIA JAKOŚCIOWE PRZESTRZENI WSPÓŁCZESNEGO KAMPUSU W BADANIACH I PROJEKTACH STUDENTÓW WYDZIAŁU ARCHITEKTURY POLITECHNIKI ŚLĄSKIEJ
}

\author{
Dorota Winnicka-Jastowska
}

\section{Architecture of universities. Selected quality criteria for the space of a contemporary university campus in research and projects of students at the Faculty of Architecture of the Silesian University of Technology}

Abstract: The education of architects at the Faculty of Architecture of the Silesian University of Technology in the field of architectural design is based on scientific research. Researchbased design means asking research questions and formulating answers supported by research methods that students learn during the course of their studies. The paper discusses a student didactic and research project carried out as a part of a semester course. The research concerned the evaluation of the functional, behavioural and organizational criteria indicated on the University campus, carried out using the Post-Occupancy Evaluation method (POE). The scope of the research included the following criteria: way-finding and buildings visual identification, universal design, services on the campus, network of learning and social contact places, design out crime issues, aesthetics of the university campus, and the campus as a space for social integration. The final part of the paper also presents selected student projects carried out on the basis of conclusions from the described research.

Keywords: architecture, urban planning, smart cities, university, campus, qualitative research in architecture, research-based design, Silesian University of Technology 
Zarys treści: Kształcenie przyszłych architektów na Wydziale Architektury Politechniki Śląskiej w zakresie projektowania architektonicznego oparte jest na badaniach naukowych. Research-based design to w praktyce stawianie pytań i formułowanie odpowiedzi wsparte metodam badawczymi, które studenci poznaja w toku studiów. W artykule omówiono studencki projekt dydaktyczno-naukowy, zrealizowany na Wydziale Architektury Politechniki Śląskiej. Badania dotyczyły ocen w zakresie wybranych kryteriów funkcjonalnych, behawioralnych i organizacyjnych w kampusie Uczelni, przeprowadzonych metodą Post-Occupancy Evaluation (POE). Zakres objął następujące kryteria badawcze: identyfikację wizualną kampusu i budynków oraz odnajdywanie celu, projektowanie uniwersalne, usługi w kampusie, siec miejsc do uczenia się i kontaktów społecznych, bezpieczeństwo, wizerunek dzielnicy akademickiej oraz kampus jako przestrzeń integracji społecznej. W końcowej częśi artyk zostały również zaprezentowane wybrane projekty studenckie, zrealizowane na podstawie wniosków z opisanych badań.

Stowa kluczowe: architektura, urbanistyka, inteligentne miasta, uniwersytet, kampus, badania jakościowe w architekturze, research-based design, Politechnika Śląska

\section{Wstęp}

Kształcenie przyszłych architektów na Wydziale Architektury Politechniki Śląskiej w zakresie projektowania architektonicznego oparte jest na badaniach naukowych. Research-based design stosuje się w twórczym procesie projektowania architektonicznego. Oprócz rozważań natury teoretycznej pierwszoplanową rolę odgrywają w nim doświadczenia zdobyte w badaniach naukowych. Research-based design to w praktyce stawianie pytań i formułowanie odpowiedzi wsparte metodami badawczymi, które studenci poznają w toku studiów. Podstawą opracowania tematu badawczego i jego zakresu, zrealizowanego w ramach dydaktyki, były wnioski z badań przeprowadzonych wcześniej przez autorkę ${ }^{1}$. Zostały w nich wyłonione kluczowe kryteria, które powinny być spełnione w projektowaniu przestrzeni uniwersyteckiej: identyfikacja wizualna kampusu i budynków oraz odnajdywanie celu, projektowanie uniwersalne, usługi w kampusie, sieć miejsc do uczenia się i kontaktów społecznych, bezpie-

Dr hab. inż. arch. Dorota Winnicka-Jasłowska, prof. PŚ jest pracownikiem Katedry Projektowania

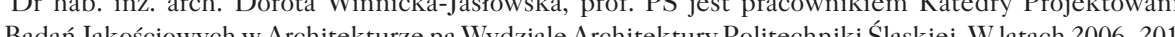
i Badań Jascion. Wéch prowadziła autorskie badania $w$ obiektach uczelni wyzszzych, jak równieź w przestrzeniach kampusów uniwersyteckich w Polsce i za granicą. Dorobek autorki to liczne publikacje omawiające przeprowadzone badania jakosciowe, zawierające whioski oraz kryteria jakostiowe architektoniczne i urbanistyczne, dotyczące pizestrzeni wyższych uczelni (Winnicka-jasłowska 2014, 2016, 2017, 2018). Podsumowanie autorskich badań stanowi jej monografta habilitacyjna pt. Przestrzen nauki wspotczesnego uniwersytelu. Ro he badan przedprojektowych w programowaniu nowych funkcli wysszych uczelmi (2016). Przeprowadzone wcześniej badania w kampusie Politechniki Sląskiej, które zostały opisane w tejże monografii, a także wniosk tealizow nego przez studentów, opisanego w niniejszym artykule. czeństwo, wizerunek dzielnicy akademickiej oraz kampus jako przestrzeń integracji społecznej, jak również ich charakterystyki.

Opisane badania wykonała grupa studentów Wydziału Architektury Politechniki Śląskiej pod kierunkiem autorki².

\section{Geneza nowych potrzeb funkcjonalno-użytkowych we współczesnych uniwersytetach}

Analizując rozwój historyczny uniwersytetu jako instytucji zajmującej się głównie prowadzeniem badań naukowych i kształceniem studentów, można stwierdzić, że w ciągu wieków przeszedł on rewolucyjną drogę w zakresie rozwoju dziedzin i dyscyplin, przemian technologicznych, metodologicznych, społecznych, a także sposobów organizacji pracy naukowej i dydaktycznej. Ewolucja ta wiąże się z koniecznymi zmianami w kształtowaniu przestrzeni architektonicznej i urbanistycznej obiektów oraz terenów uniwersyteckich, służącymi wsparciu głównych zadań stawianych uczelniom, a więc kształceniu, prowadzeniu badań naukowych oraz bardzo istotnej w tych procesach interakcji społecznej. W każdym stuleciu rozwój przestrzeni uniwersyteckiej był odpowiedzią na ówczesne potrzeby organizacyjne związane z realizowaniem tych głównych zadań. Obecnie, w dobie dynamicznego rozwoju technologii informacyjnych, uniwersytet staje się przestrzenią nauki bez granic, platformą rozwoju wszystkich dziedzin i dyscyplin nauki, upowszechniając ją na wiele sposobów, a także obszarem nowych aktywności i relacji społecznych (Winnicka-Jasłowska 2016).

Wraz z rozwojem technologii informacyjnych dokonują się zmiany w sposobach pozyskiwania wiedzy, jej przetwarzania, a także w zakresie metod kształcenia. Rozwój ów wpłynął na nowe sposoby uczenia się i nauczania oraz unowocześnił narzędzia do ich wspierania. Studenci poszukują zarówno źródeł wiedzy, jak i większych możliwości współpracy i zdobywania doświadczeń z wykorzystaniem technik zdalnych (ang. distance learning). Rozwój sieci informatycznych oraz środków pracy związanych z przepływem informacji usprawnił procesy kształcenia oraz wpłynął na łatwiejsze pozyskiwanie wiedzy i zarządzanie nią. Aktywności wynikające z nowych form pracy wymuszają nowe relacje i interakcje w przestrzeni budynków. Sam proces zdobywania wiedzy przebiega obecnie wszędzie, nie tylko w salach wykładowych, ale również w kontaktach społecznych bezpośrednio, drogą elektroniczną, na wiele różnych sposobów. Przemianom uległy metody komunikowania się, współpracy, podejmowania

${ }^{2}$ Przedstawione badania wykonała grupa 32 studentów Wydziału Architektury Politechniki Śląskiej pod kierunkiem autorki, w ramach przedmiotu. Metody badań jakości budynków i przestrzeni urbanistycznej”, w trakcie 5. semestru studiów I stopnia, w roku akademickim 2017/2018. 
wspólnych działań i inicjatyw, a także organizacji życia najliczniejszej części środowiska akademickiego - studentów. To właśnie oni stanowią grupę najbardziej podatną na zmiany technologiczne, informacyjne i społeczne. Najłatwiej podążają za zmianami i w pełni potrafią z nich korzystać. Głównie młodych ludzi określa się mianem społeczeństwa informacyjnego. Zatem istotny wpływ na kształtowanie przestrzeni uniwersyteckiej ma wiedza architektów o tym, jakie są współczesne formy i metody pracy oraz interakcji społecznych, aby dobrze zaprojektowane budynki były wsparciem dla użytkowników.

Podstawową formą rozwoju i kształtowania przestrzeni uniwersyteckiej jest wiedza o potrzebach użytkowych. W XXI w. mamy do czynienia z nowym wizerunkiem przestrzennym uczelni, opartym na następujących podstawowych założeniach:

- zastosowanie technologii informacyjnych (ICT),

- ścisła współpraca z partnerami zewnętrznymi,

- oczekiwania studentów, ich styl życia, charakterystyczne cechy społeczeństwa informacyjnego,

- interakcja społeczna w zakresie uczenia się i pozyskiwania wiedzy (Winnicka-Jasłowska 2016)

Aby dobrze zaprojektować przestrzeń kampusów uniwersyteckich, należy skupić się na tych założeniach. Podstawowymi aspektami mającymi wpływ na rozwiązania funkcjonalno-przestrzenne współczesnych uniwersytetów są praca i jej formy. Zmieniły się sposoby uczenia się i aktywności społeczeństwa informacyjnego, przybierając różne, dowolne formy zależne od potrzeb. Obecnie nowe obiekty uczelni zarówno w Polsce, jak i w Europie Zachodniej budowane są tak, by uwzględnić nowe sposoby pracy, uczenia się i potrzeby społeczne. Przestrzeń uniwersytecka powinna zapewniać możliwość realizowania wielu typów aktywności związanych ze zdobywaniem wiedzy i umiejętności. Należą do nich przede wszystkim:

- kontakty społeczne, możliwość spotykania się w mniejszych lub większych grupach w sposób formalny i spontaniczny,

- praca grupowa w mniejszych lub większych zespołach, zaplanowana lub doraźna, - uczenie się zdalne i/lub poprzez kontakty społeczne,

- wypoczynek, przebywanie w różnych miejscach, swobodne użytkowanie przestrzeni do indywidualnych celów poza zajęciami.

Model funkcjonalno-przestrzenny uczelni oparty jest głównie na założeniach pierwotnych. W Europie uczelnie rozwijają się przez dodawanie nowych obiektów i nowych funkcji do starszej tkanki. W ten sposób następuje rozbudowa kampusu. W Polsce kampusy są tworzone przez obiekty o różnych funkcjach, w tym głównie siedziby wydziałów, jak również obiekty administracyjne, sportowe, usługowe, socjalne (akademiki, hotele dla pracowników wizytujących) i inne. Obecnie rola kampusu jest inna, znacznie ważniejsza niż dawniej. Teren uniwersytetu stanowi przedłużenie funkcji obiektów uczelnianych. Rolą terenów uniwersyteckich jest nie tylko komunikacja, rekreacja czy jedynie estetyczne zagospodarowanie obszarów wokół budynków. Nade wszystko pełnią one, podobnie jak budynki uniwersyteckie, funkcję wspierania interakcji społecznych, które z kolei sprzyjają działalnośc naukowej oraz dydaktycznej uczelni. Stąd tak ważna jest świadomość tego faktu w procesie kształtowania przestrzeni kampusów, w jej strefowaniu, zagospodarowywaniu i aranżacji. Społeczeństwo informacyjne oczekuje nowatorskich, ciekawych rozwiązań architektonicznych, które uczynią przestrzeń atrakcyjną, przychylną relacjom społecznym i bezpieczną (Winnicka-Jasłowska 2016).

\section{Politechnika Śląska - zmiany funkcjonalno-przestrzenne i ich wpływ na jakość użytkową kampusu}

Znaczącym przedsięwzięciem Politechniki Śląskiej była przebudowa obszaru dzielnicy akademickiej, stanowiącego główny kampus Uczelni ${ }^{3}$. Miało to miejsce w latach 2012-2014. Działania objęły przebudowę dróg, placów, zieleni i parkingów oraz instalacji ziemnych. Uporządkowano place przed budynkami, zaprojektowano zieleń o charakterze rekreacyjnym i ozdobnym, a także przekształcono główną ulicę Akademicką w ciąg pieszo-jezdny z ograniczonym ruchem kołowym. Działanie to nie tylko zmieniło organizację ruchu, ale też wpłynęło na poprawienie ogólnego wizerunku kampusu (fot. 1, 2, 3). Wraz ze zmodernizowaną przestrzenią pojawiły się nowe sposoby jej użytkowania, zarówno przez studentów, jak i pracowników oraz mieszkańców miasta. Gdy zakończono przebudowę kampusu w 2014 r., wprowadzone zmiany stały się tematem wielu dyskusji i ocen (Winnicka-Jasłowska i in. 2016, 2017, 2018), a także polem badawczym i projektowym dla studentów w ramach zajęć programowych. Realizowane były również tematy projektowe dydaktyczne w zakresie zagospodarowania terenów wokół budynków uczelni, uzupełnienia kampusu o nowe obiekty z funkcjami wspierającymi oraz działania aranżacyjne, takie jak np. projekt stref pracy plenerowej, które miałyby stanowić przestrzenie wspierające naukę i odpoczynek.

Politechnika Śląska powstała w 1945 r., a jej główne etapy rozwoju pod względem inwestycyjnym przebiegały w latach 60., 80., 90. XX w., a następnie w latach 2004-2014. Natomiast od 2014 r. do chwil obecnej widoczne jest na niej wprowadzanie zmian o charakterze doskonalącym w zakresie wyposażenia obiektów i technologii energooszczędnych. Przez dziesięciolecia niejednorodna była dynamika przemian modernizacji, zależna najpierw od czynników politycznych, a potem ekonomicznych kraju. Ostatn etap jest wynikiem większej świadomości i umiejętnosci definiowania potrzeb uczelni, a także wiedzy władz i projektantow o tym, jak należy przestrzeń zmieniac, by podnosic jej jakośc uzy tkową. Po 2004 działaniem była modernizacja przestrzeni kampusu w latach 2012-2014. 


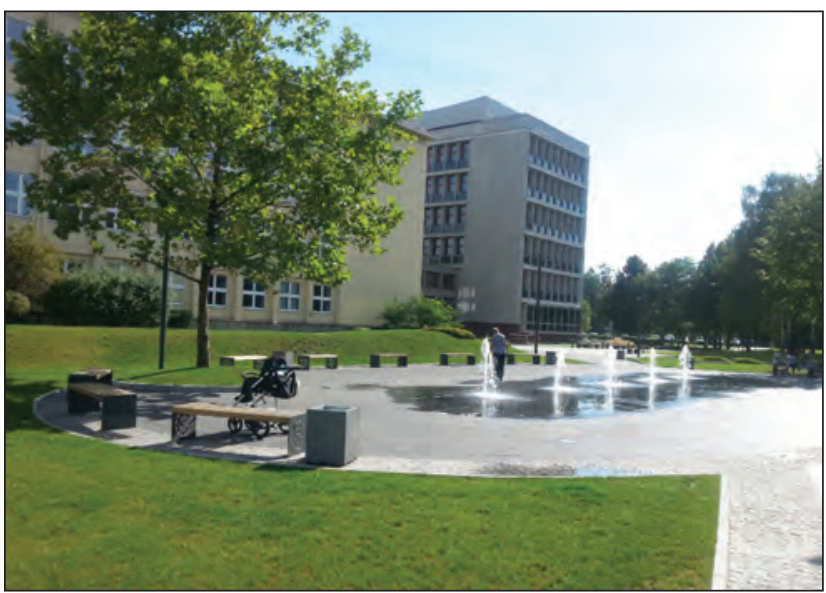

Fot. 1. Kampus Politechniki Śląskiej po modernizacji. Budynki Wydziału Budownictwa oraz Wydziału Architektury

(fot. D. Winnicka-Jasłowska) Photo 1. Campus of the Silesian University of Technology after modernization. Buildings of the Faculty of Civil Engineering and the Faculty of Architecture (photo by D. Winnicka-Jasłowska)

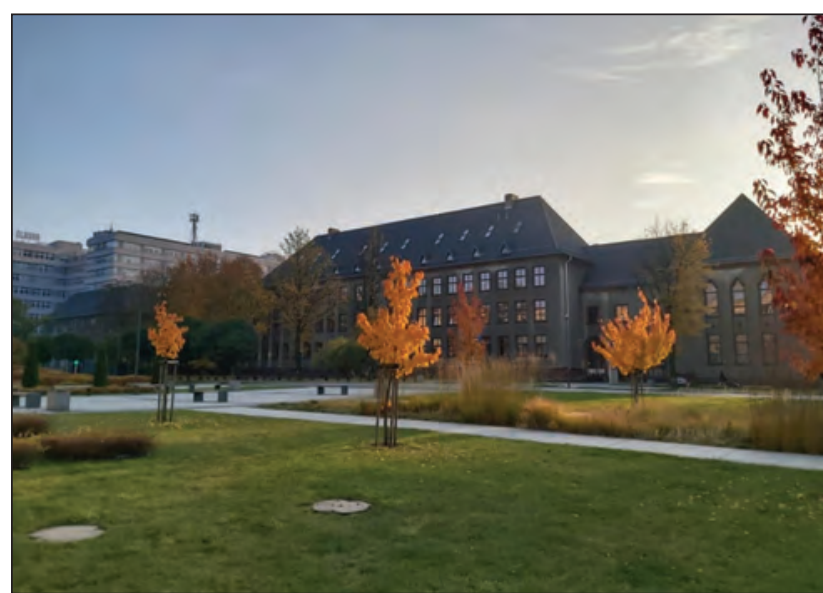

Fot. 2. Kampus Politechniki Śląskiej po modernizacji. Widok budynku Wydziału Elektrycznego

(fot. D. Winnicka-Jasłowska) Photo 2. Campus of the Silesian University of Technology after modernization. View of the Faculty of Electrical Engineering building (photo by D. Winnicka-Jasłowska)

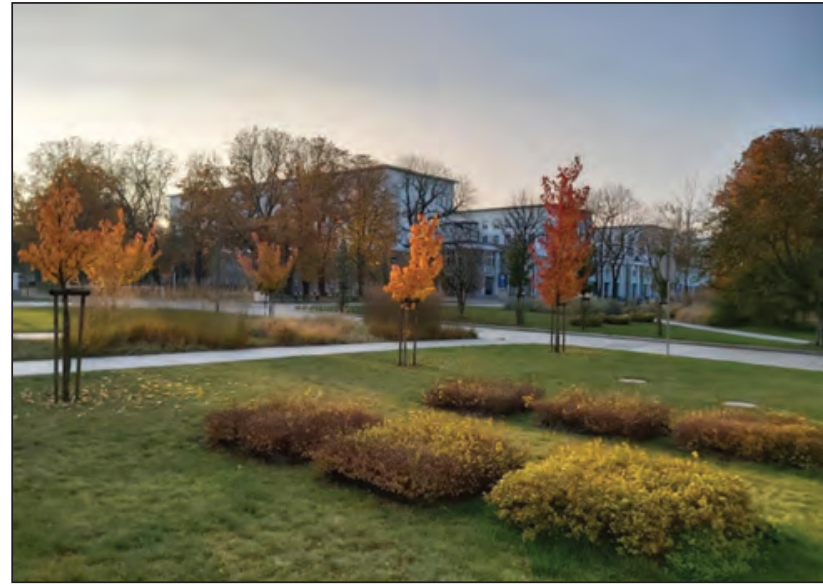

Fot. 3. Kampus Politechnik Śląskiej po modernizacji. Widok na ul. Akademicką

(fot. D. Winnicka-Jasłowska) Photo 3. Campus of the Silesian University of Technology after modernization. View of the Akademicka street

(photo by D. Winnicka-Jasłowska)

\section{Cel i zakres badań w kampusie Politechniki Śląskiej.} Metoda i techniki badawcze zastosowane w projekcie

Głównym celem omawianych badań jest ocena jakości kampusu według siedmiu wybranych kryteriów, mających największy wpływ na jakość użytkową terenów Uczelni. Metodą badawczą zastosowaną w projekcie jest POE (ang. Post-Occupancy Evaluation) (Preiser i in. 1988). POE stosowana jest w ocenie jakości przestrzeni architektonicznej i urbanistycznej w trakcie użytkowania, a także jako praktyczn metoda pozyskiwania wiedzy o użytkownikach i ich potrzebach.

Metodę POE wykorzystuje się do oceny jakości: funkcjonalnej, technicznej, organizacyjnej i behawioralnej. POE w zakresie jakości funkcjonalnej służy do badani potrzeb użytkowych i oceny poziomu zadowolenia z użytkowanej przestrzen budynków, do przeprowadzania ocen eksperckich dotyczących funkcjonalnośc rozwiązań przestrzennych. W efekcie ma zastosowanie praktyczne, gdyż wniosk z badań mogą się przyczynić do programowania i modyfikacji układu przestrzennego, zmian funkcji budynku, poprawy aranżacji i innych działań projektowych, służących podnoszeniu jakości użytkowej. W zakresie jakości behawioralne tę metodę stosuje się głównie do poprawy jakości środowiska fizycznego budynku, zwłaszcza w odniesieniu do przestrzeni pracy, w szeroko pojętej ergonomii, w tym wyposażenia pomieszczeń oraz ich mikroklimatu, do ulepszania estetyki budynku z zewnątrz i wewnątrz. W tym przypadku wykonuje się szczegółową analizę jakościową z udziałem użytkowników. POE może również posłużyć do weryfikacji rozwiązań systemu informacji w budynku oraz na badanym terenie lub w zespole budynków (problematyka tzw. odnajdywania celu, ang. way-finding). W ramach POE analizować można problemy behawioralne, związane $\mathrm{z}$ zachowaniem ludzi w przestrzeni architektonicznej, a zwłaszcza aspekty terytorialności, prywatności, preferencji estetycznych.

W zakresie jakości technicznej POE stosuje się do analiz oraz modyfikowani i modernizowania technicznego oraz technologicznego budynków, a także do eliminowania przyczyn SBS, czyli syndromu chorego budynku (ang. SBS - Sick Building Syndrome).

Ponadto metoda POE jest skuteczna w zakresie poznawczym i rozwoju wiedzy o użytkownikach, funkcjach budynków, potrzebach użytkowych i ich realizowaniu w przestrzeni zbudowanej. Opisując studia przypadków, można dokonywać porównań, zarówno pod względem metodologii prowadzenia badań, jak i wniosków z analiz obiektów o podobnej funkcji. Konkluzje z wielokrotnych studiów przypadków mogą być pomocne w programowaniu i projektowaniu kolejnych budynków o takiej samej lub podobnej funkcji. Istotą badań jest zastosowana metoda postępowania scenariusz badań i narzędzia badawcze opracowane pod kątem danego tematu. Badania metodą POE mogą mieć również praktyczne zastosowanie w projektach 
architektonicznych, służąc do formułowania wniosków lub wytycznych projektowych dla budynków o danych funkcjach (Preiser i in. 1988).

W ramach zajęć dydaktycznych studenci zrealizowali projekt badawczy opisany w niniejszym artykule. Jego zakres objął: analizy urbanistyczne, badania eksperckie oraz badania z udziałem użytkowników. Początkowo w ramach analiz urbanistycznych określono nieformalne granice kampusu. Podstawą graficznego planu kampusu było naniesienie na niego użytkowanych przez studentów i pracowników budynków należących do Uczelni, a także obiektów usługowych w przestrzeni miasta, które są niezbędne do funkcjonowania kampusu (ryc. 1).

Najważniejszą częścią badań była ocena ekspercka i partycypacyjna terenu kampusu w zakresie siedmiu kryteriów uznanych za istotne dla sprawności funkcjonalnej ${ }^{4}$.

- identyfikacja wizualna kampusu, odnajdywanie celu (ang. way-finding),

- projektowanie uniwersalne,

- usługi w kampusie i usługi zewnętrzne,

- sieć miejsc do uczenia się i kontaktów społecznych,

- bezpieczeństwo w kampusie (ang. design out crime),

- wizerunek uczelni,

- dzielnica akademicka jako przestrzeń integracji.

W opisywanym studenckim projekcie badawczym wykonano początkowo wizję lokalną, a następnie sporządzono listę kryteriów i problemów (ang. check list), które miały zostać poddane ocenie.

Następnie przeprowadzono ocenę ekspercką i partycypacyjną z udziałem studentów Wydziałów, których budynki przylegają do ul. Akademickiej - głównej drogi pieszo-jezdnej kampusu Politechniki Śląskiej. Przeprowadzono wywiady z wykorzystaniem uprzednio opracowanych kwestionariuszy. Oceniono poziom zadowolenia studentów w zakresie: dostępności, usług, sieci miejsc do uczenia się, integracji społecznej, bezpieczeństwa oraz wizerunku uczelni. W badaniach wzięło udział 120 studentów, proporcjonalnie wybranych z każdego Wydziału: Górnictwa, Inżynierii Bezpieczeństwa i Automatyki Przemysłowej; Elektrycznego; Automatyki, Elektroniki i Informatyki; Architektury oraz Budownictwa. Wywiad miał charakter sondażu i uwzględniał związek respondenta $\mathrm{z}$ budynkiem Wydziału, na którym studiuje. Po podsumowaniu odpowiedzi okazało się, że lokalizacja budynku użytkowanego przez danego studenta miała wpływ na jego punkt widzenia i odpowiedzi.

W projekcie została dokonana ocena ekspercka następujących kryteriów: identyfikacja wizualna, odnajdywanie celu, projektowanie uniwersalne i dostępność, usługi w kampusie i usługi zewnętrzne, bezpieczeństwo oraz wizerunek uczelni.

${ }^{4}$ Kryteria uznane za istotne, wpływające dodatnio na jakość użytkową kampusu - na podstawie badan autorskich D. Winnickiej-Jasłowskiej (2016).

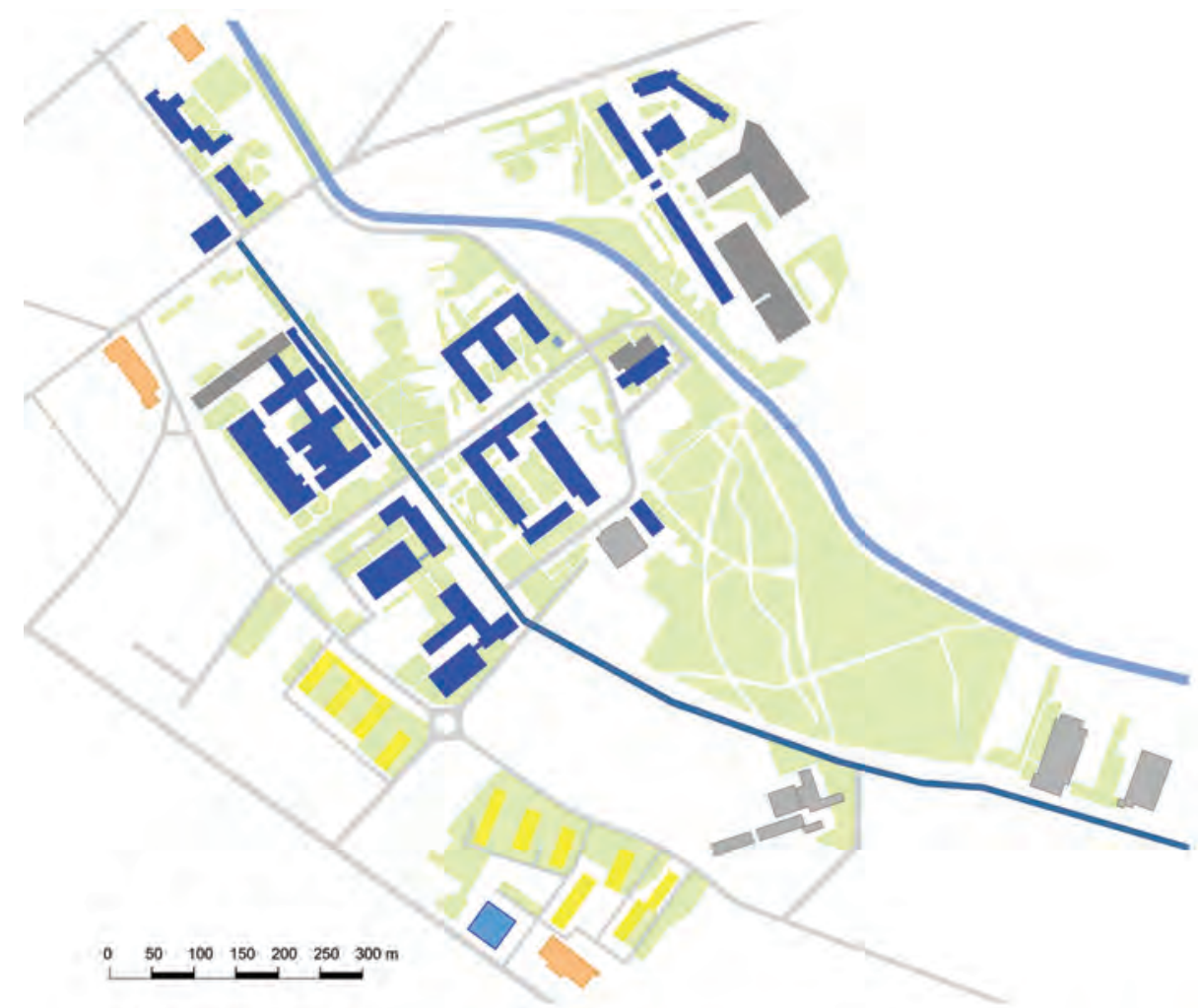

LEGENDA

BUDYNKI WYDZIAŁÓW POLITECHNIKI ŚLĄSKIEJ

OBIEKTY ZWIAZZANE Z KULTURĄ STUDENCKA (MROWISKO)

DOMY STUDENCKIE

OBIEKTY USŁUGOWE I FUNKCJE ŻYWIENIOWE

OBIEKTY SPORTOWE

OBIEKTY WSPÓLNE, OGÓLNOUCZELNIANE DYDAKTYCZNE,

NAUKOWO-DYDAKTYCZNE

TERENY ZIELONE

RZEKA KŁODNICA

UL. AKADEMICKA

Ryc. 1. Plan kampusu Politechniki Śląskiej (autor: Paula Jaworek)

Fig. 1. Plan of the Silesian University of Technology Campus (author: Paula Jaworek) 
Badania eksperckie polegały na ocenie kryteriów zawartych w liście sprawdzającej (ang. check list). Zastosowano tu metody obserwacyjne, które studenci opracowal według ułożonego wcześniej scenariusza i planu obserwacji. Efektem podsumowania badań była ocena opisowa dotycząca sposobu, w jaki dane kryterium jest realizowane na terenie kampusu, a także stopnia jego realizacji w miejscu wskazanym na planie. Uzupełnieniem danych na temat realizacji kryteriów były wnioski z wywiadów z użytkownikami. Przykładowo, w przypadku kryteriów takich jak identyfikacja wizualna i odnajdywanie celu studenci analizowali sposoby oznaczeń obiektów, doprowadzania do celu, podkreślenia osi, place centralne przedwejściowe, miejsca charakterystyczne itp., szukali map i planów kampusu, obserwowali poruszanie się na jego terenie ludzi. Dopełnieniem tych informacji były pytania skierowane głównie do studentów I roku, które dotyczyły ich pierwszych kontaktów z uczelnią, łatwości znajdywania celu i oznaczeń budynków.

W zakresie projektowania uniwersalnego studenci analizowali przede wszystkim nawierzchnie - ich rodzaj, równość, gładkość, poślizg, stan utrzymania, a nade wszystko rozwiązania architektoniczne stref wejściowych i stopień dostępności do budynków. Usługi w kampusie i usługi zewnętrzne oceniali na bazie własnych doświadczeń oraz wywiadów ze studentami z wymienionych Wydziałów. Następnie dane nanosili na mapę, tworząc w ten sposób zakres funkcjonowania kampusu i jego umowne granice.

Badanie sieci miejsc do uczenia się i kontaktów społecznych polegało na udaniu się do budynków i wskazaniu w nich tzw. stref studenta, czyli miejsc użytkowanych przez studentów w czasie wolnym od zajęć. Zostały one umownie zaznaczone w budynkach wydziałowych, przylegających do ul. Akademickiej, a także przed budynkami, w których znajdują się miejsca do odpoczynku. Wskazano również miejsca z potencjałem stref pracy plenerowej. We wnioskach pojawiły się postulaty studentów wszystkich Wydziałów, aby utworzyć przy budynkach takie miejsca, w których studenci mogliby spędzać czas, ucząc się i pracując. Znalazły się tam również opinie dotyczące jakości i efektywności miejsc przeznaczonych do uczenia się indywidualnego lub zespołowego na poszczególnych Wydziałach.

Analiza kampusu pod względem bezpieczeństwa polegała na sporządzeniu dokumentacji zdjęciowej miejsc potencjalnie niebezpiecznych. Respondenci wskazali takie miejsca, które ich zdaniem są przede wszystkim słabo oświetlone, rzadko uczęszczane lub zarośnięte zielenią krzaczastą ograniczającą widoczność. Dane o tych strefach zostały zaznaczone na planie. We wnioskach określono sposoby na ich ulepszenie, aby zwiększyć ich bezpieczeństwo. Wskazano m.in. funkcje uzupełniające, które poprawiłyby bezpieczeństwo danej strefy i spowodowały częstsze korzystanie z niej, np. mobilne funkcje żywieniowe w postaci food trucków, dodatkowe oświetlenie lub uporządkowanie zieleni, zwłaszcza na obszarach peryferyjnych kampusu.
Wizerunek uczelni był oceniany pod kątem: stanu utrzymania technicznego budynku i stref wejściowych, utrzymania zieleni, nawierzchni, czystości. Wskazywane były szczególne walory estetyczne krajobrazu, jak również wartość obiektów historycznych, ich stan utrzymania, detal, co jest niezmiernie ważne w tym kryterium. Studenci Wydziału Architektury skupiali się na estetyce, stylach architektonicznych budynków uczelni oraz na walorach krajobrazowych kampusu. Cenne były spostrzeżenia studentów innych wydziałów, którzy przeważnie nie oceniali walorów estetycznych obiektów, a jedynie ich stan utrzymania.

Kryterium dzielnica akademicka jako przestrzeń integracji było oceniane metodą zarówno wywiadu, jak i obserwacji. Respondenci wskazali miejsca, gdzie najchętniej gromadzą się studenci. Określono również, dlaczego są to miejsca lubiane przez studentów oraz dlaczego niektóre miejsca zaaranżowane jako przestrzeń przeznaczona do rekreacji lub pobytu ludzi nie pełnią dobrze tej funkcji.

W badaniach studenci zastosowali poznane techniki, takie jak: wywiady z wykorzystaniem kwestionariuszy pytań, listy kryteriów w ocenie eksperckiej, obserwacje oraz dokumentowanie za pomocą nagrywania filmów, zapisów tekstowych, fotograficznych lub rysunków. Badania ukierunkowane były na rozpoznanie potrzeb dotyczących projektowanej przestrzeni, a także na ocenę stanu istniejącego kampusu z punktu widzenia studentów. Przeprowadzono również wywiady z kilkoma pracownikami z wykorzystaniem kwestionariuszy pytań, jednak grupa ta, niewielka pod względem liczebności, nie wniosła istotnych informacji do prowadzonych badań. Zastosowano metody obserwacyjne, polegające na przeanalizowaniu, w jaki sposób studenci funkcjonują w przestrzeni kampusu - gdzie najchętniej siadają, gromadzą się i inicjują swoje aktywności. Obserwacje zostały zapisane w postaci filmów, fotografii, a wnioski przedstawiono w prezentacji końcowej.

\section{Wyniki badań}

W rezultacie przeprowadzonych badań sprecyzowano wnioski dotyczące siedmiu problemów badawczych:

1. Identyfikacja wizualna kampusu i budynków, odnajdywanie celu - przeanalizowano kampus pod względem identyfikacji wizualnej i rozwiązań systemu informacji. W tym celu przeprowadzono wywiady ze studentami I roku studiów I stopnia z wydziałów przylegających do ul. Akademickiej. Celem wywiadów było ustalenie, czy informacja o obiektach i ich rozmieszczeniu w kampusie jest łatwa do odczytania. Czy główne dojścia do budynków są wystarczająco dobrze oznakowane graficznie? We wnioskach stwierdzono, że brakuje map przy najważniejszych, umownych wejściach na teren kampusu. Poza tym oznaczenia budynków są widoczne, ale powinny być nowocześniej zaprojektowane, 
np. przy użyciu koloru, symboli graficznych lub logotypów wydziałów. Stwier dzono też, że w sposobach informowania nie uwzględniono osób niedowidzących i niewidomych. Na podstawie wniosków studenci przygotowali prezentację z inspiracjami dotyczącymi rozwiązań systemowych i graficznych, jakie można by zastosować na terenie Politechniki Śląskiej ${ }^{5}$

2. Projektowanie uniwersalne - wykonano badania dostępności dla każdego potencjalnego użytkownika. Obecnie, po modyfikacji, kampus stanowi przyjazną przestrzeń dla wszystkich grup użytkowników - nie tylko dla osób z niepełnosprawnościami, ale też dla seniorów i rodziców z małymi dziećmi. Podniesienie walorów użytkowych przyczyniło się do większego zainteresowania mieszkańców miasta rekreacją i spędzaniem czasu wolnego w dzielnicy akademickiej. Ulica Akademicka jako aleja pieszo-jezdna, jak również place przed budynkami, ścieżki i ich styk z ulicami jezdnymi zostały zaprojektowane zgodnie z zasadami projektowania uniwersalnego. Nawierzchnia wielofakturowa, wykonana z kostek i płyt granitowych, nie stanowi utrudnienia w poruszaniu się. Problemy pojawiają się w strefach głównych wejść do budynków. Nie wszystkie rozwiązania są zgodne z zasadami projektowania uniwersalnego i nie wszystkie wpływają korzystnie na dostępność, zwłaszcza w przypadku osób z niepełnosprawnościami ruchowymi ${ }^{6}$.

3. Usługi w kampusie i usługi zewnętrzne - funkcjonalność przestrzeni publicznej, jak już wspomniano, uwzględnia zakres dostępności oraz użytkowanie przez mieszkańców miasta. Każdy mieszkaniec miasta może poruszać się bez ograniczen w przestrzeni kampusu. Teren uczelni, dzięki nowym rozwiązaniom w obrębie funkcji rekreacyjnych, małej architektury (np. fontanna), stał się atrakcyjną przestrzenią miejską zarówno dla studentów i pracowników uczelni, jak i dla mieszkańców miasta. Bliskość kampusu do centrum miasta sprawia, że to ono zapewnia brakujące funkcje usługowe. Dzielnica akademicka natomiast stanowi atrakcyjną przestrzeń spacerowo-rekreacyjna, której naturalnym rozszerzeniem są miejskie tereny rekreacyjno-sportowe (Park Chrobrego, MOSiR) zlokalizowane w sąsiedztwie.

4. Sieć miejsc do uczenia się i kontaktów społecznych - analiza w trakcie badań pozwoliła na wskazanie przestrzeni uczelni, które powinny zostać zmodyfikowane pod względem aranżacji i wyposażenia, tak aby studenci mogli tam spędzać czas między zajęciami, uczyć się, integrować i odpoczywać. W wyniku przeprowadzonych badań oceniono, że wyposażenie i przystosowanie większości miejsc do studentów nie jest zadowalające. Takie miejsca istnieją, ale nie są one zaopatrzone w wygodne i estetyczne meble, nie zawsze też znajdują się

\footnotetext{
Od 2019 r. Politechnika Śląska ma nowy system identyfikacji wizualnej w obrębie kampusu.

Obecnie Politechnika Śląska realizuje program Uczelnia dostępna (2020-2022).
}

w ich pobliżu punkty gastronomiczne, które umożliwiłyby korzystającym z nich osobom dłuższe przebywanie w tych miejscach. Wyjątek stanowi Wydział Automatyki, Elektroniki i Informatyki, gdzie powstała nowoczesna strefa studenta, która jest chętnie użytkowana?.

5. Bezpieczeństwo w kampusie (ang. design out crime) - na podstawie badań została przeprowadzona analiza miejsc potencjalnie niebezpiecznych. Powstała mapa wskazująca miejsca, które należałoby lepiej oświetlić i przyciąć zieleń, która zbyt rozrośnięta, może powodować poczucie zagrożenia, a nawet stanowić realne zagrożenie, np. tworząc otoczenie sprzyjające napadom. Takie miejsca znajdują się w okolicy nabrzeża rzeki Kłodnicy.

6. Wizerunek uczelni - analizowano walory estetyczne obiektów uczelni. Okazało się, że studenci innych kierunków niż architektura uważają budynek za ładny wtedy, gdy jest on dobrze utrzymany technicznie. Nie skupiają się w swych ocenach na jego architekturze. Ponadto, budynki wydziałowe i ważne obiekty wspierające powinny nosić znamiona własnej tożsamości, tzn. wzniesione w określonym czasie, powinny zachować styl tego okresu. Uczelnia zachowuje swoją tożsamość poprzez „nawarstwienie” obiektów z różnych okresów jej historii rozwoju. Obecnie Politechnika Śląska posiada obiekty z różnych okresów: przedwojenne, $z$ lat 50., 60., 70., 90. i powstałe lub remontowane po roku 2000. Wszystkie są w doskonałym stanie technicznym i świadczą o dynamicznym rozwoju Uczelni.

7. Dzielnica akademicka jako przestrzeń integracji - w trakcie badań dokonano próby odpowiedzi na pytanie: czy przestrzeń kampusu Politechniki Śląskiej sprzyja kontaktom społecznym? Okazuje się, że w skali całego kampusu raczej nie. Brak obiektów wyłącznie o funkcjach gastronomicznych nie sprzyja dłuższym kontaktom w przestrzeni kampusu. Inaczej wygląda to w budynkach wydziałowych, gdzie znajdują się bufety i kawiarnie, w których chętnie przebywają studenci w oczekiwaniu na zajęcia lub w przerwie między nimi. W opiniach respondentów są to miejsca najbardziej sprzyjające kontaktom społecznym o charakterze nieformalnym. Również tzw. strefy studenta, które powstają obecnie w kolejnych budynkach wydziałowych, stanowią miejsca do nauki, odpoczynku oraz wspólnego przebywania i integracji. Mają one znaczący wpływ na zmiany w sposobie użytkowania przestrzeni uczelni, a także na zwyczaje studentów.

Badania zostały przeprowadzone w 2017 r., gdy dopiero wskazywano na problem braku sieci miejsc do uczenia się. W 2020 r. taka sieć już powstała. W budynkach wydziałowych wygospodarowano przestrzenie przeznaczone dla studentów, które zostały ciekawie zaprojektowane. Kilka budynków jest w trakcie realizacji tzw. stref studenta. 
Projekty studenckie powstałe na podstawie wniosków z badań

Na bazie opisanych badań i sformułowanych wniosków studenci w kolejnym roku podejmowali różne tematy projektowe związane z kampusem. Na uwagę zasługuja m.in. projekty konkursowe tzw. stref studenta, organizowane kilkukrotnie dla różnych budynków, np. strefa studenta Wydziału Architektury oraz strefa studenta przy Rektoracie (ryc. 2, 3), a także projekty strefy pracy plenerowej studentów Wydziału Architektury ${ }^{8}$. Pierwszy temat dotyczył projektu aranżacyjnego miejsc w budynku

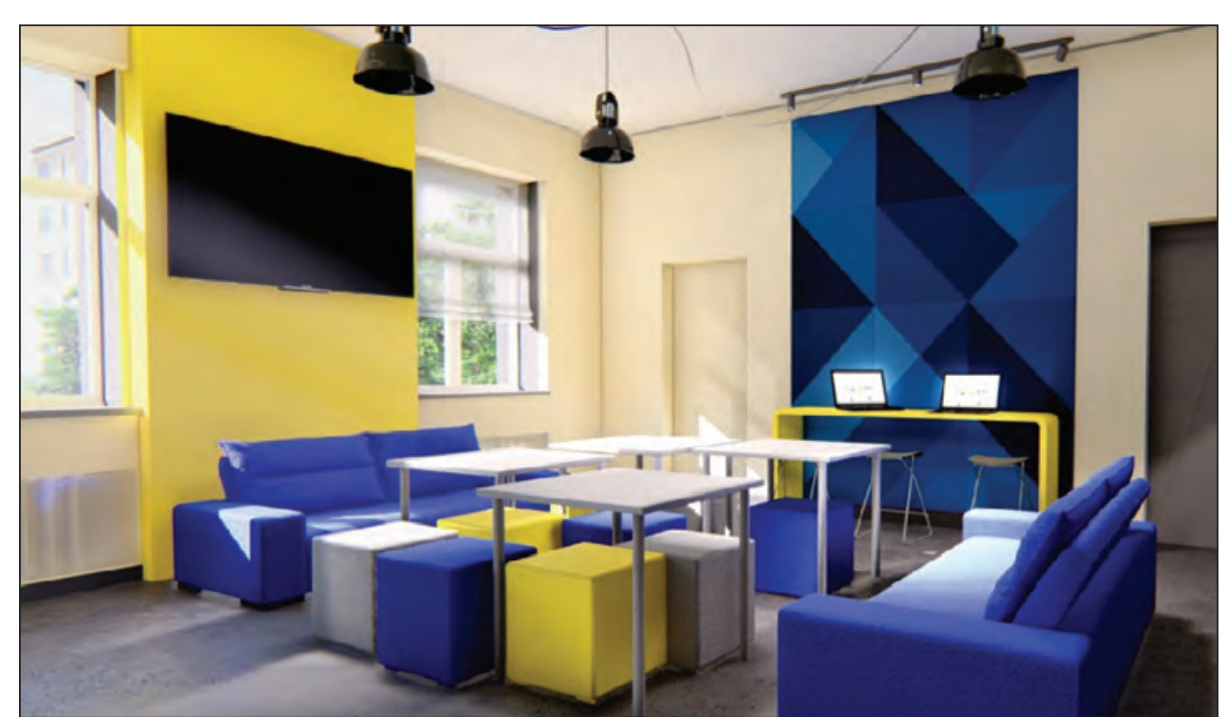

Ryc.2. Projekt strefy studenta przy Rektoracie. Nagroda Główna: Paula Jaworek, Artur Gała. Projekt wykonawczy: Paula Jaworek, Artur Gała, Dorota Winnicka-Jasłowska, Jerzy Wojewódka. Projekt w trakcie realizacji (2020)

Fig. 2. Project of the student zone at the Rector's Office. Main Prize: Paula Jaworek, Artur Gała. Executive project: Paula Jaworek, Artur Gała, Dorota Winnicka-Jasłowska, Jerzy Wojewódka. Project in progress (2020)

${ }^{8}$ Strefa pracy plenerowej studentów Wydziału Architektury - projekt zrealizowany w ramach przedmiotı „Ergonomia w architekturze” w 4. semestrze studiów I stopnia, pod kierunkiem dr hab. inż. arch. Doroty Winnickiej-Jasłowskiej, Prof. PŚ. Konkurs na strefę studenta Wydziału Architektury - organizatorami konkursu studenckiego byli Dziekan Wydziału Architektury dr hab. inż. arch. Klaudiusz Fross, Prof. PS oraz Prodziekan ds. Kształcenia dr hab. inż. arch. Dorota Winnicka-Jasłowska, Prof. PS. Konkurs na strefę studenta przy Rekto-
racie - organizatorem był Rektor PŚ we współpracy z dr hab. inż. arch. Dorotą Winnicką-Jasłowską, Prof. PŚ
Wydziału, które mają być przeznaczone dla studentów do pracy, odpoczynku i uczenia się. Koncepcja strefy pracy plenerowej została opracowana na podstawie opisanych badań. Powstały projekty zagospodarowania terenu przy budynku Wydziału Architektury, a następnie propozycja zagospodarowania tarasu przy Rektoracie.

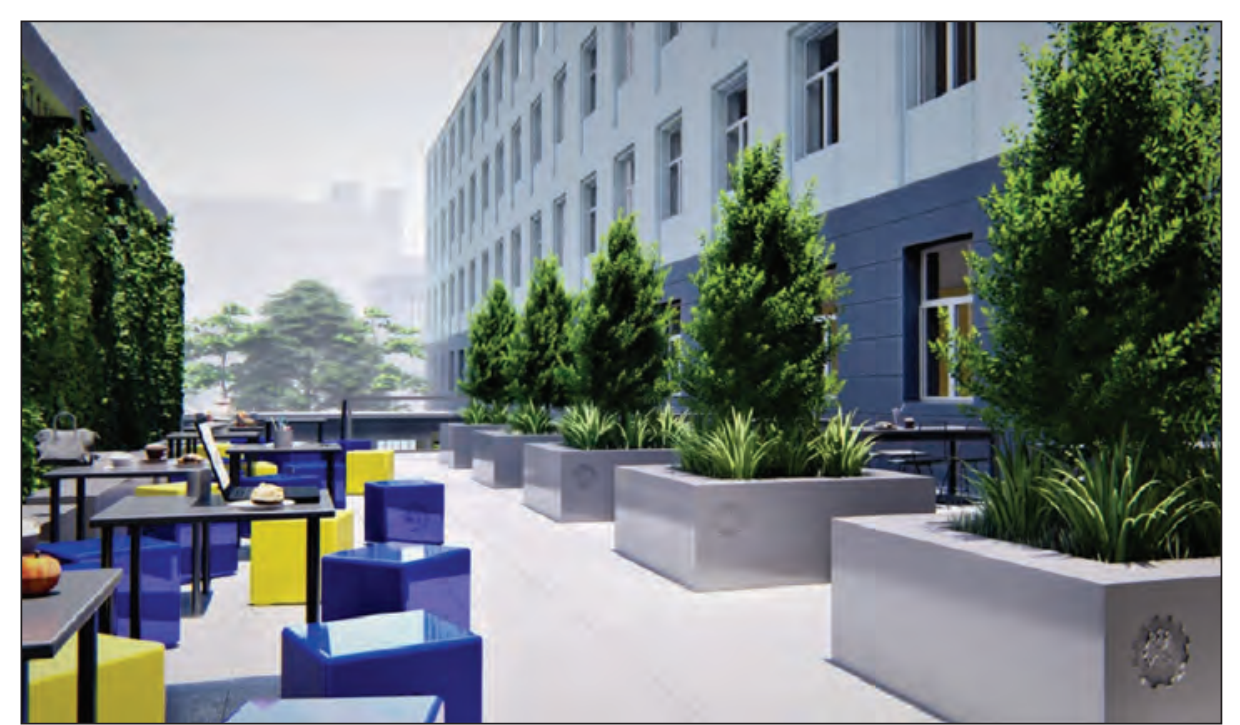

Ryc. 3. Projekt strefy studenta przy Rektoracie. Koncepcja zagospodarowania tarasu na strefę pracy plenerowej. Nagroda główna: Paula Jaworek, Artur Gała. Projekt wykonawczy: Paula Jaworek, Artur Gała, Dorota Winnicka-Jasłowska, Jerzy Wojewódka. Projekt w trakcie realizacji (2020)

Fig. 3. Project of the student zone at the Rector's Office. The concept of a terrace as an outdoor work area. Main Prize: Paula Jaworek, Artur Gała. Executive project: Paula Jaworek, Artur Gała, Dorota Winnicka-Jasłowska, Jerzy Wojewódka. Project in progress (2020)

\section{Podsumowanie}

Studenci przeprowadzili badania jakościowe w kampusie Politechniki Śląskiej w ramach projektu semestralnego, według 7 kryteriów istotnych dla jakości użytkowej. Są to: identyfikacja wizualna kampusu i budynków, odnajdywanie celu, projektowanie uniwersalne, usługi w kampusie i usługi zewnętrzne, sieć miejsc do uczenia się i kontaktów społecznych, bezpieczeństwo w kampusie, a także aspekty estetyczne i stan utrzymania kampusu. Nadrzędnym problemem badawczym była 
ocena dzielnicy akademickiej jako przestrzeni wspierającej procesy kształceni i rozwój nauki. Analizowane kryteria badawcze mają znaczący wpływ na sprawność funkcjonalną przestrzeni i są to:

1. Dostępność dla każdego, z uwzględnieniem dzieci i młodzieży szkolnej (uczestnicy zajęć popularyzujących naukę), a także osób starszych (uniwersytety III wieku) i z niepełnosprawnościami. Dotyczy ona zarówno terenów akademickich, jak i budynków.

2. Funkcjonalność i atrakcyjność przestrzeni publicznych terenów uniwersyteckich, które uwzględniają dostępność oraz użytkowanie przez mieszkańców miasta.

3. Łączenie funkcji nauki z funkcjami komercyjnymi i rekreacyjnymi dla potrzeb użytkowników uczelni oraz mieszkańców.

4. Sieć miejsc do uczenia się indywidualnego i zespołowego w przestrzeniach ogólnodostępnych.

5. Ergonomia rozwiązań aranżacyjnych przestrzeni ogólnodostępnych.

6. Informacja - system graficznych oznaczeń w przestrzeniach ogólnodostępnych budynków i kampusu, które umożliwiają łatwe, a także intuicyjne poruszanie się i użytkowanie przestrzeni.

W zaprezentowanych projektach studenckich uwzględniono natomiast 3 najważniejsze warunki:

1. Konieczność integracji środowiska akademickiego poprzez nowatorskie, elastyczne rozwiązania architektoniczne, zwłaszcza w strefach ogólnodostępnych.

2. Wymóg konkurencyjności, możliwy między innymi przez zapewnienie wysokiej jakości rozwiązań przestrzennych i aranżacyjnych porównywalnych z innymi ośrodkami akademickimi zarówno w kraju, jak i za granicą.

3. Przestrzenie dla nowych form pracy i uczenia się, kontaktów nieformalnych oraz wypoczynku.

Projekt badawczy zrealizowany przez studentów i opisany w niniejszym artykule miał za zadanie przede wszystkim zwrócenie ich uwagi na umiejętność pozyskiwania i analizowania informacji dotyczących potrzeb użytkowych w celach projektowych. Pokazał, jak złożone problemy stoją przed projektantami i w jaki sposób je analizować, by następnie umiejętnie rozwiązać je projektowo. Mówiąc o funkcjonalności i sprawności przestrzeni kampusu, nie myślimy wyłącznie o budynkach, ale też o wielu innych aspektach sprzyjających organizacji pracy, życia akademickiego, a także o indywidualnych potrzebach użytkowników zaspokajanych w całej przestrzeni kampusu. Zadanie badawcze miało więc wymia dydaktyczny, a wyniki badań zostały wykorzystane w studenckich projektach semestralnych. Władze uczelni wykazały duże zainteresowanie przeprowadzonymi badaniami. Rektor i Prorektorzy Politechniki Śląskiej wzięli udział w wernisażu wystawy prac studenckich Student w przestrzeni akademickiej, które powstały na podstawie wniosków z opisanych badań. Została ona zorganizowana z inicjatywy autorki niniejszego artykułu na Wydziale Architektury Politechniki Śląskiej w roku akademickim 2017/2018.

\section{Literatura}

Fross K., Winnicka-Jasłowska D., Sempruch A., 2018, Student zone as a new dimension of learning space. Case study in Polish conditions, [w:] J. Charytonowicz (red.), Advances in human factors, sustainable urban planning and infrastructure, Proceedings of the AHFE 2017 International Conference on Human Factors, Sustainable Urban Planning and Infrastructure, July 17-21, 2017, Los Angeles, California, USA, Cham, Springer International Publishing, 77-83.

Preiser W., Rabinowitz H., White E., 1988, Post-Occupancy Evaluation, Van Nostrand, Reinhold, NY.

Tymkiewicz J., Winnicka-Jasłowska D., Fross K., 2019, The campus space in research and student projects, [w:] J. Charytonowicz, C. Falcao (red.), Advances in human factors, sustainable urban planning and infrastructure, Proceedings of the AHFE 2018 International Conference on Human Factors, Sustainable Urban Planning and Infrastructure, July 21-25, 2018, Loews Sapphire Falls Resort at Universal Studios, Orlando, Florida, USA, Cham, Springer International Publishing.

Winnicka-Jasłowska D., Tymkiewicz J., Fross K., 2019, Open-air work zones for students at the Faculty of Architecture depicted on the basis of pilot student projects, [w:] J. Charytonowicz (red.), The 9th International Conference on Applied Human Factors and Ergonomics (AHFE) 2018 and the Affiliated Conferences to be held at the Loews Sapphire Falls Resort, Universal Studios Orlando, Florida, USA July 22-26, 2018, Cham, Springer Internationa Publishing.

Winnicka-Jasłowska D. (red.), 2014, Jakość wspótčesnych uniwersytetów wo opiniach ü̇ytkowników i w studenckich koncepcjach projektowych, Wydawnictwo Politechniki Śląskiej, Gliwice.

Winnicka-Jasłowska D., 2016, Przestrzeń nauki wespótczesnego uniwersytetu. Rola badań przedprojektowych w programowaniu nowych funkcji wyższych uczelni, Wydawnictwo Politechniki Śląskiej, Gliwice.

Dorota Winnicka-Jastoreska (ORCID:0000-0003-4201-2985)

Politechnika Slask

Wydziat Architektury

Katedra Projektowania i Badań Jakościowych w Architekturze

ul. Akademicka 7, 44-100 Gliwice

Dorota.winnicka-jaslowska@polsl.pl 
